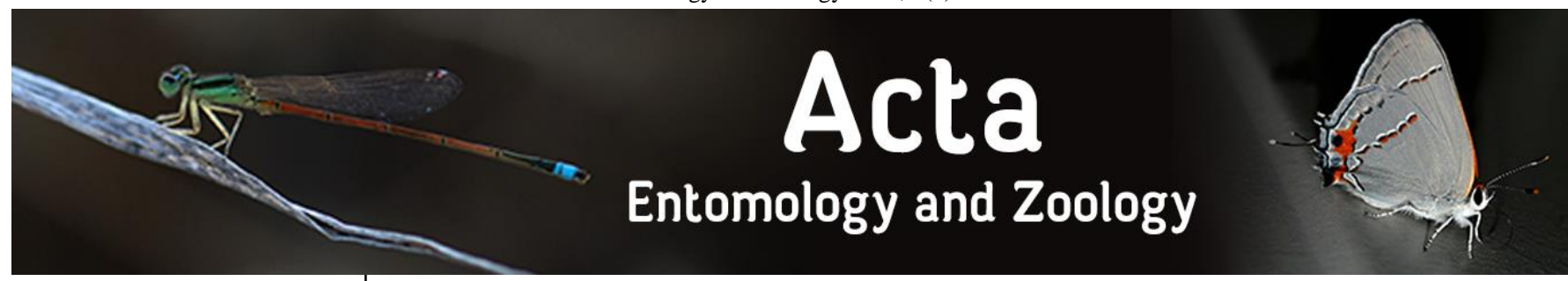

E-ISSN: 2708-0021 P-ISSN: 2708-0013 www.actajournal.com AEZ 2020; 1(2): 17-19 Received: 08-05-2020 Accepted: 12-06-2020

Agnes Deepa A Conservation Biology Laboratory, Department of Zoology, Bharathiar

University, Coimbatore, Tamil Nadu, India

Gunasekaran C

Conservation Biology

Laboratory, Department of

Zoology, Bharathiar

University, Coimbatore, Tamil

Nadu, India

\section{G Shobana}

Bharathiyar Arts and Science College for Women,

Deviyakuruchi, Salem, Tamil

Nadu, India
Corresponding Author:

Agnes Deepa A

Conservation Biology

Laboratory, Department of

Zoology, Bharathiar

University, Coimbatore, Tamil

Nadu, India

E-mail:

agnesconservation@gmail.com

\section{Abundance and Phylogeny of lepidopteran species in and around Karamadai area Coimbatore district Tamil Nadu South India}

\author{
Agnes Deepa A, Gunasekaran C and G Shobana
}

DOI: $\underline{\text { https://doi.org/10.33545/27080013.2020.v1.i2a.13 }}$

\begin{abstract}
Lepidoptera are a diverse and charismatic group of insects that have received significant taxonomic and systematic attention. Lepidoptera are members of natural shrub-grassland communities. The documented butterflies were belonging to the family Papilionidae, Nymphalidae, Lycaenidae, Hesperiidae during the study period May 2018 to April 2019 by using transect counting method in Karamadai area. Totally 2,280 individuals belonging to 43 species of butterflies were documented in three different study area namely Human altered area, Agriculture area and scrub jungle area and the diversity of species were calculated by using Shannon-Weiner index. A comprehensive phylogeny is constructed to examine the origins and species diversity for Papilionidae, Nymphalidae, Lycaenidae, Hesperiidae, since the phylogeny is the proposition, universally accepted in the scientific community, that plants or animals of different species descended from common ancestors. The habitat place major role for the abundance of the lepidopteron diversity.
\end{abstract}

Keywords: Abundance, lepidoptera, phylogeny, Karamadai, Shannon-weiner index

\section{Introduction}

Butterflies are a large group of insects, belonging to the order "Lepidoptera". This refers to the characteristic feature that distinguishes them from most other insects. The butterfly diversity is high in the tropics compared to temperate regions of the world ${ }^{[1]}$. Although only a quarter of India's butterfly diversity is represented in the Western Ghats, it has the characteristic of high alpha diversity of butterflies in certain locations ${ }^{[2]}$. According to modern evolutionary theory, all organisms on earth have descended from a common ancestor, which means that any set of species, extant or extinct, is related. This relationship is called a phylogeny and it is represented by phylogenetic trees which graphically explain the evolutionary history related to the species of interest. The COI appears to process a great range of phylogenetic signals, showing fast rate of nucleotide substitution that not only enable the discrimination of cryptic species, but also can reveal phylogeographic structure within a species ${ }^{[3]}$. Keeping this in view present study was conducted.

\section{Materials and Methods}

The study area is located in the Coimbatore district, the state of Tamilnadu, India. The study was conducted from May 2018 to April 2019 in Karamadai area and the area is situated approximately between $11.27 \hat{\mathrm{A}}^{\circ} \mathrm{N}$ and $76.97 \hat{\mathrm{A}}^{\circ} \mathrm{E}$. It also rises to a height of 353 meters or 1158 feet above the mean sea level. Encompassing with 203 villages. The survey was made in all the villages by transect method in different plots like human altered area, Agriculture area and scrub jungle area.

The COI nucleotide sequences of each species were retrieved from National Center for biotechnology information. Multiple sequences of the retrieved sequences from were performed using CLUSTALW with default paprameters in MEGA 5.0 [4]. By using CLUSTALW program distance matrix by pair wise sequence divergence was calculated and for constructing the combined phylogenetic tree for lepidoteran species. The multiple sequence output from CLUSTALW was saved and executed in MEGA5.0 to generate Neighbor-joining tree using bootstrapping analysis. 


\section{Results and Discussion}

The survey was done and totally 2,280 Lepidoptera species were surveyed. The total individuals were belonging to 43 species of butterflies were documented in three different study area namely Human altered area, Agriculture area and scrub jungle area. The species were belonging to the family Papilionidae, Nymphalidae, Lycaenidae, Hesperiidae during the study period (Fig. 1). The phylogenetic results provides a high support for Nymphalidae and the relationships among other three families in order Lepidoptera (Fig. 2) and the (table 1) shows the retrieved sequence of butterflies.

Agricultural sites had significantly more butterflies than non-agricultural sites ${ }^{[5]}$. But in case of this study the species abundance shows very high scrub forest, fallowing that the species abundance is more in agriculture area and the human altered area shows low abundance. Butterflies have traditionally been viewed as an excellent group of bioindicators, mainly due to complexity of ecological management required by many species ${ }^{[6,7]}$.

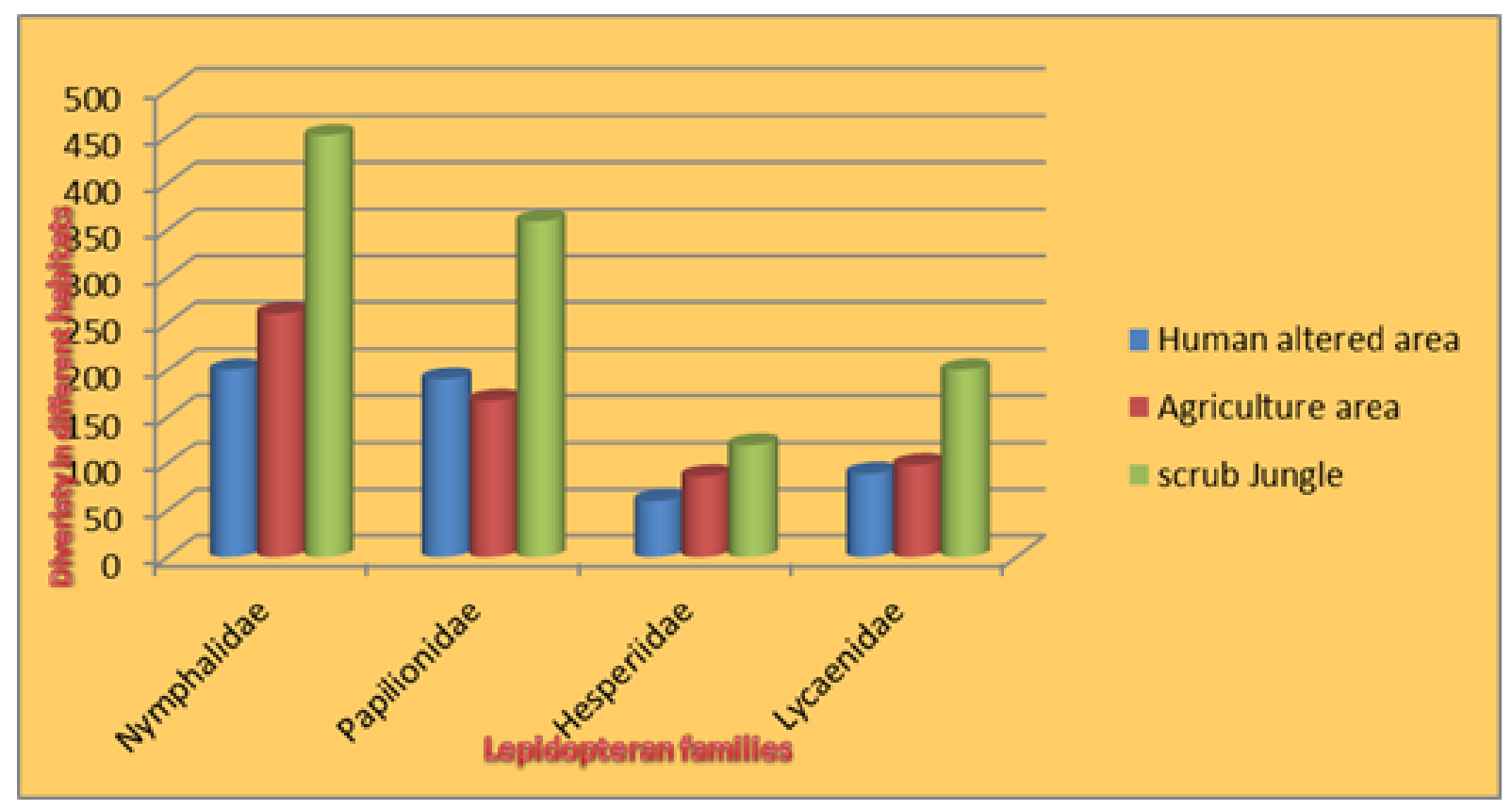

Fig 1: Shows the Abundance of Lepidoptearn

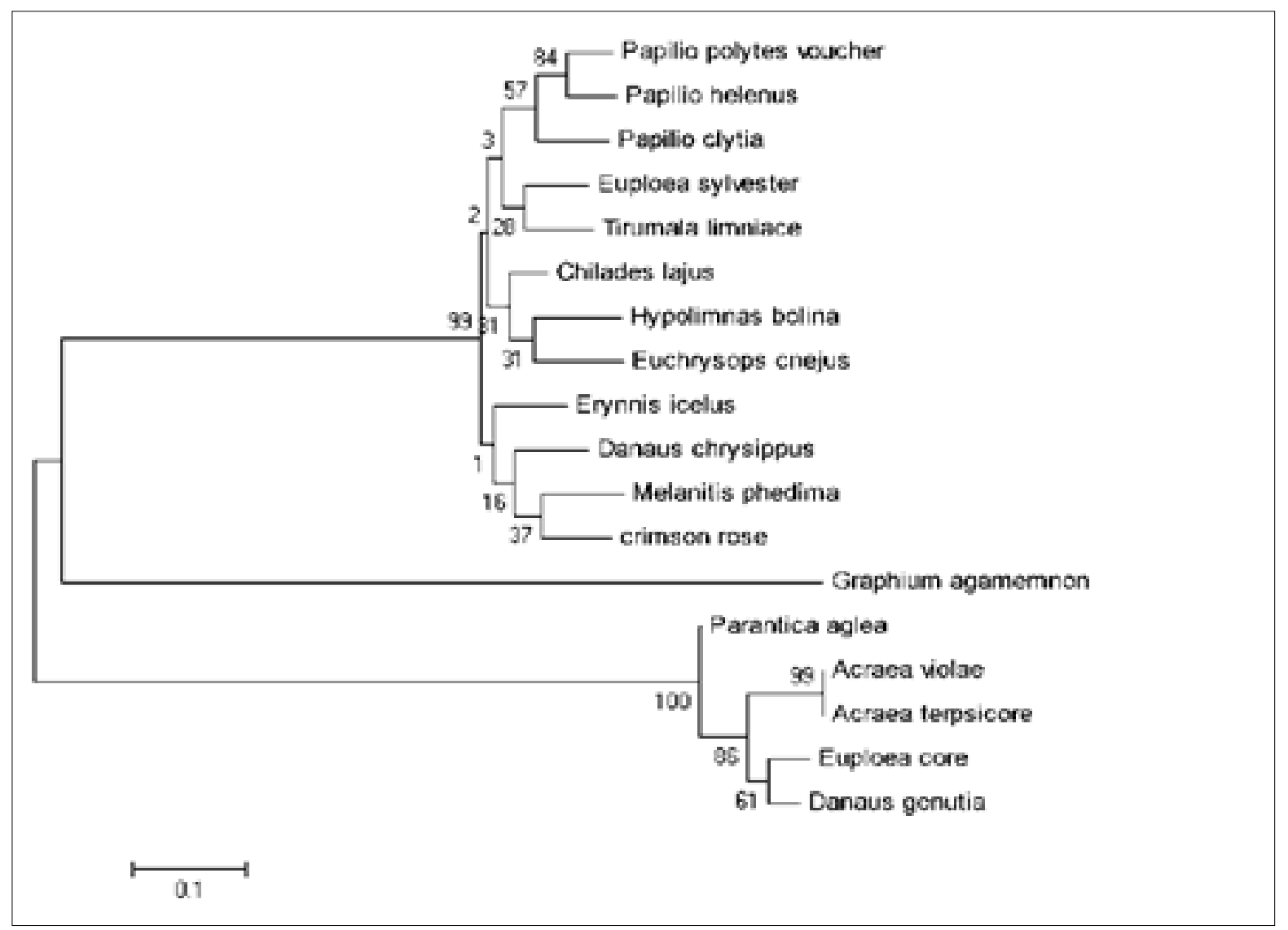

Fig 2: Shows the Cladogram of Lepidoptera species 
Table 1: Retrieved sequence of Butterflies

\begin{tabular}{|c|c|c|c|c|c|}
\hline S. No & Family & Species Name & Gene & Genbank Accession No & Sequence length (bp) \\
\hline 1 & Nymphalidae & Euploea Sylvester & $\mathrm{COI}$ & KC306721.1 & 600 \\
\hline 2 & Nymphalidae & Acraea violae & $\mathrm{COI}$ & JX226067.1 & 610 \\
\hline 3 & Nymphalidae & Euploea core & $\mathrm{COI}$ & KC306729.1 & 470 \\
\hline 4 & Nymphalidae & Danaus genutia & $\mathrm{COI}$ & KC306724.1 & 429 \\
\hline 5 & Nymphalidae & Danaus chrysippus & $\mathrm{COI}$ & AF394193.2 & 676 \\
\hline 6 & Nymphalidae & Parantica aglea & $\mathrm{COI}$ & KC306718.1 & 645 \\
\hline 7 & Nymphalidae & Tirumala limniace & $\mathrm{COI}$ & KC306727.1 & 616 \\
\hline 8 & Nymphalidae & Melanitis phedima & $\mathrm{COI}$ & HQ962147.1 & 658 \\
\hline 9 & Nymphalidae & Acraea terpsicore & $\mathrm{COI}$ & JQ614099.1 & 658 \\
\hline 10 & Nymphalidae & Hypolimnas bolina & $\mathrm{COI}$ & GU091500.1 & 627 \\
\hline 11 & Hesperiidae & Erynnis icelus & $\mathrm{COI}$ & GU088761.1 & 579 \\
\hline 12 & Papilionidae & Graphium agamemnon & $\mathrm{COI}$ & AB377325.1 & 707 \\
\hline 13 & Papilionidae & Papilio polytes & $\mathrm{COI}$ & HQ962338.1 & 658 \\
\hline 14 & Papilionidae & crimson rose (Atrophaneura hector) & $\mathrm{COI}$ & JX261944.1 & 631 \\
\hline 15 & Papilionidae & Papilio helenus & $\mathrm{COI}$ & EU792497.1 & 688 \\
\hline 16 & Papilionidae & Papilio clytia & COI & HM246468.1 & 661 \\
\hline 17 & Lycaenidae & Chilades lajus & $\mathrm{COI}$ & GQ128946.1 & 2238 \\
\hline 18 & Lycaenidae & Euchrysops cnejus & COI & GQ129020.1 & 2238 \\
\hline
\end{tabular}

The phylogenetic tree shows that the origin of the cladogram was from Papilo polytes and Papilo helenus, and the both species were present in same clades. The total divergence of the species from Papilo polytes and Papilo helenus extended up to Graphium agamemnon. The origin of the another branch was Parantica aglea and extended upto Euploea core and Danus genutia. This phylogenetic tree reveals the evolutionary relationship between the families of Nymphalidae, Hesperiidae, Papilionidae and Lycaenidae.

\section{Conclusion}

The purpose of present investigation is to understand the butterfly diversity and to number of individual's diversity and species richness in Karamadai area in Coimbatore district and the $\mathrm{CO} 1$ is a conserved gene and therefore they can be used for the butterfly species. If a particular gene is not altered by the environmental influences, it is then proved to be an ideal gene for tracing the evolutionary studies and species identification which was determined from phylogenetic analysis. We have to take necessary action to conserve the species in karamadai region especially for Lepidoptera.

\section{References}

1. Raghavendra Gowda HT, Vijaya Kumara, Pramod AF, Hosetti BB. Butterfly diversity, seasonality and status in lakkavalli range of Bhadra Wildlife Sanctuary, Karnataka. World Journal of Science and technology. 2011; 1(11):67-72 ISSN: 2231-2587

2. Gaonkar H. Butterflies of the Western Ghats, India, including Sri Lanka: a biodiversity assessment of a threatened mountain system. Unpublished report, 1996, $51 \mathrm{p}$.

3. Hebert. PDN, Ratnasingham S, deWaard JR. Barcoding animal life: cytochrome c oxidase subunit 1 divergences closely related species. Proceedings of the Royal Society B Biological Sciences. 2003; 270:S96S99.

4. Tamura K, Peterson D, Peterson N, Stecher G, Nei M, Kumar S. MEGA5: Molecular Evolutionary Genetics Analysis using Maximum Likelihood, Evolutionary Distance, and Maximum Parsimony
Methods. Molecular Biology and Evolution. 2011; 28:2731-2739.

5. Erica Fleishman, George T Austin, Peter F Brussard, Dennis D Murphy. A comparison of butterfly communities in native and agricultural riparian habitats in the Great Basin, Biological Conservation, USA. 1999; 89:209-218.

6. Thomas JA. Rare species conservation: case studies of European butter Xies. In: Spellerberg, I.F., Goldsmith, F.B., Morris, M.G. (Eds.), The ScientiWc Management of Temperate Communities for Conservation. Blackwell ScientiWc Publishers, Oxford, 1991, 149198 p.

7. New TR, Pyle RM, Thomas JA, Thomas CD, Hammond PC. Butterfly conservation management. Annual Review of Entomology. 1995; 40:57-83. 